\title{
АНАЛІЗ ХІРУРГІЧНОГО ЛІКУВАННЯ ДІТЕЙ 3 КІСТАМИ ПЕЧІНКИ В НАЦІОНАЛЬНІЙ ДИТЯЧІЙ СПЕЦІАЛІЗОВАНІЙ ЛІКАРНІ «ОХМАТДИТ»
}

\author{
А. О. Біленко, С. О. Никитюк \\ Херсонський базовий медичний коледж \\ Національна дитяча спеціалізована лікарня “ОХМАТДИТ», м. Київ \\ ДВНЗ «Тернопільський державний медичний університет \\ імені І. Я. Горбачевського МОЗ Украӥни»
}

У статті проаналізовано результати діагностики та лікування дітей з кістами печінки.

\section{ANALYSIS OF SURGICAL TREATMENT OF CHILDREN WITH LIVER CYSTS IN NATIONAL CHILDREN’S SPECIALIZED HOSPITAL «OKHMATDYT»}

\author{
A. O. Bilenko, S. O. Nykytyuk \\ Kherson basic medical college \\ National Children's Specialized Hospital «OKHMATDYT», Kyiv \\ I. Horbachevsky Ternopil State Medical University
}

The article analyzes the results of diagnostics and treatment of children with liver cysts.

Вступ. На сьогодні єдиним можливим радикальним методом лікування кіст печінки (КП) признаний хірургічний. Основними труднощами, з якими стикаються хірурги-гепатологи, $є$ те, що у дітей ехінококоз схильний до експансивного та полісегментарного росту; великі та гігантські КП небезпечні можливою перфорацією, морфологічні зміни в ураженому органі $\epsilon$ причиною інвалідизації та летальності, відсутня посегментна топографо-анатомічна діагностика $[1,4,5,8]$. У цій галузі дитячої хірургії спостерігають 17,4-64,0% післяопераційних ускладнень, а рецидив захворювання досягає 7,7-15,0 \% [3, 7, 10]. Найчастішими ускладненнями в лікуванні КП є нагноєння залишкової порожнини кісти та поява жовчних нориць $[2,6,9,11]$.

Мета роботи: оцінити результати хірургічного лікування дітей з КП.

Основна частина. Проаналізовано дані лікування 287 дітей з кістами печінки віком від 1 місяця до 18 років, які перебували в клініках дитячої хірургії Національного медичного університету імені О. О. Богомольця. У 212 (73,87 \%) дітей виявлено ехінококові кісти печінки (ЕКП), а у 75 (26,13\%) пацієнтів були непаразитарні кісти печінки (НКП) (табл. 1).

(ㄱ А. О. Біленко, С. О. Никитюк, 2018 у Національній дитячій спеціалізованій лікарні (НДСЛ) «ОХМАТДИТ» використовували і вважають важливою та доцільною посегментну діагностику локалізації КП, оскільки даний розподіл допомагав краще орієнтуватися в анатомо-топографічній характеристиці цієї патології, що, в свою чергу, дозволяло раціонально визначитись із хірургічним доступом та вибрати оптимальний обсяг і характер втручання.

У 212 пацієнтів з ехінококозом виявлено 353 кісти печінки. Дрібні кісти (за А. Т. Пулатовим, 1994) було виявлено у 39 (11,05 \%) дітей, малі - у 161 (45,61 \%), середні - у 116 (32,86 \%), великі - у 21 (5,95\%) та гігантські - в 16 (4,53 \%) пацієнтів.

Солітарні ЕКП мали 147 (69,34 \%) пацієнтів. У 65 (30,66 \%) дітей з множинним ехінококозом виявлено 206 кіст. По 2 кісти печінки діагностовано у 41 (19,34\%) дитини, в 11 (5,19\%) - по 3 кісти, і в 7 (3,30 \%) хворих було по 4 кісти печінки. Ураження печінки по 5 і більше кіст спостерігали в одиничних випадках.

Серед всього загалу 100 (28,33 \%) кіст локалізувались в лівій частці печінки, 247 (69,97\%) - у правій частці печінки, а 6 (1,70 \%) кіст займали сегменти (IV-V) лівої та правої часток печінки. В лівій частці 
Таблиця 1. Характеристика пацієнтів із кістами печінки та жовчних шляхів

\begin{tabular}{|l|c|c|c|c|c|}
\hline \multirow{2}{*}{ Характер патології } & \multicolumn{3}{|c|}{ Вік пацієнтів (роки) } & \multirow{2}{*}{ Всього } \\
\cline { 2 - 5 } & $<1$ & $1-5$ & $6-10$ & $>10$ & $212(73,87 \%)$ \\
\hline Ехінококові кісти печінки & 29 & 65 & 82 & 36 & $75(26,13 \%)$ \\
\hline Непаразитарні кісти печінки & 29 & 25 & 14 & 7 & 287 \\
Всього & 58 & 90 & 96 & 43 & $(100 \%)$ \\
\hline
\end{tabular}

печінки найчастіше було ураження в IV $(12,18 \%)$ та в III (9,07 \%) сегментах. Сегменти правої частки печінки були уражені, відповідно, 12,18 \% - в V, 13,31 \% - в VI, $22,10 \%$ - в VII та 15,86 \% - в VIII сегменті. Ехінококові кісти великих та гігантських розмірів займали по дватри сегменти печінки, а в 2 випадках - локалізувались у сегментах всієї правої частки.

Великі та гігантські кісти спостерігали у 12 із 147 пацієнтів із солітарним ехінококозом, у 9 із 41 дитини з наявністю 2 ехінококових кіст, у 2 із 11 - з 3 кістами, в 1 із 7 дітей з 4 кістами та в 1 пацієнта з наявністю 11 кіст. У 4 дітей з множинним ехінококозом діагностовано по 2 великі кісти в печінці.

Ураження ехінококовими кістами лише правої частки печінки встановлено у 127 (59,90 \%) дітей, у 45 (21,23 \%) пацієнтів такі кісти були тільки в лівій частці. Комбіноване ураження обох часток печінки спостерігали у 40 (18,87 \%) дітей.

у 75 пацієнтів виявлено 88 кіст печінки непаразитарного походження. Дрібні кісти ми виявили у 10 (11,36 \%) пацієнтів, малі - у 34 (38,64 \%), середні - у $24(27,27 \%)$, великі - у 14 (15,91\%) та гігантські - в $6(6,82 \%)$ пацієнтів.

Згідно із класифікацією О. О. Шалімова (1993) справжні КП були в 12 (16,00 \%) із 75 дітей, а в 63 (84,00 \%) випадках виявили несправжні КП.

Солітарні КП діагностовано у 67 (89,33 \%) пацієнтів. У 7 (9,33 \%) дітей з множинними НКП виявлено 16 кіст. По 2 кісти печінки виявили у 5 (6,67 \%) пацієнтів, і по 3 кісти було в 2 (2,67 \%) дітей. В 1 (1,33 \%) дитини 3 вродженим полікістозом діагностовано 5 кіст.

Серед 88 виявлених у НДСЛ «ОХМАТДИТ» НКП, $53(60,23 \%)$ кісти локалізувались в правій частці, $19(21,59 \%)$ - в лівій, 3 (3,41 \%) - в обох частках і 13 (14,77 \%) кіст були навколопечінковими (в правій або лівій трикутних зв'язках). Кістозний процес найчастіше локалізувався в IV (12,50 \%) та у VII (20,46 \%) сегментах печінки. Кісти великих розмірів мали солітарний характер і уражали по декілька сегментів - від 2 сегментів до всієї правої частки печінки.

Ураження непаразитарними кістами лише правої частки печінки встановлено у 53 (70,67 \%) дітей, у
14 (18,66 \%) пацієнтів такі кісти були тільки в лівій частці. Комбіноване ураження обох часток печінки спостерігали у 8 (10,66 \%) дітей. Серед загальної кількості кіст правої частки печінки - 12 із них мали великі та гігантські розміри. В лівій частці печінки була тільки 1 велика кіста. При кістозному ураженні обох часток печінки обов'язково були кісти великих і гігантських розмірів. Значний обсяг правої та лівої часток займали солітарні кісти у 3 пацієнтів. У правій трикутній зв'язці печінки виявлено 9 солітарних кіст, а при ураженні лівої трикутної зв'язки діагностовано по 2 кісти в 2 пацієнтів.

Для встановлення діагнозу використовували клініко-лабораторні дані, ультразвукове дослідження печінки та органів черевної порожнини і заочеревинного простору, комп'ютерну томографію печінки, оглядову рентгенографію органів грудної клітки і серологічні тести.

Не оперовано 28 дітей з дрібними кістами, діаметр яких був меншим за 1 см. Пацієнтам цієї групи при ехінококозі $(n=20)$ призначали повторні курси антигельмінтних препаратів. Дітей з дрібними кістами непаразитарного генезу $(\mathrm{n}=8)$ спостерігали в динаміці. Показання для хірургічного лікування таких кіст висували при збільшенні їх розмірів.

Мета операції при КП різної етіології полягає в повному або максимальному видаленні кісти та повній облітерації залишкової порожнини.

Хірургічне лікування КП проводили на ранніх термінах та з урахуванням того, що з плином часу наявність кісти, її прогресивний ріст, розвиток паразита (при ехінококозі) неминуче призвели би до поширеності ураження, появи хронічної інтоксикації, інфекційних ускладнень, порушення функції печінки та інших життєво важливих органів. У пацієнтів із цією патологією використовували різні варіанти хірургічного втручання: відкрите (лапаротомія) або міні-інвазивне - пункційно-дренажне (транскутанна пункція) та лапароскопічне (табл. 2).

Відкритий спосіб використовували при поверхневому розташуванні кіст печінки (коли частина фіброзної оболонки кісти виступала над капсулою цього 
Таблиця 2. Варіанти лікування дітей з кістами печінки

\begin{tabular}{|c|c|c|c|}
\hline \multirow{2}{*}{ Характер лікування } & \multicolumn{2}{|c|}{ Характер патології } & \multirow{2}{*}{ Всього } \\
\hline & ЕКП & HКП & \\
\hline Консервативно + спостереження & 20 & 8 & 28 \\
\hline $\begin{array}{l}\text { Лапаротомія, інтраабдомінальна пункція, санація з дренуванням } \\
\text { під контролем ультрасонографії }\end{array}$ & 5 & - & 5 \\
\hline $\begin{array}{l}\text { Лапаротомія, інтраабдомінальна пункція, санація з дренуванням } \\
\text { під дактилотактильним контролем }\end{array}$ & 7 & - & 7 \\
\hline $\begin{array}{l}\text { Лапаротомія, пункція, санація (деепітелізація), висічення країв } \\
\text { оболонок, капітонаж }\end{array}$ & 37 & 15 & 52 \\
\hline $\begin{array}{l}\text { Лапаротомія, пункція, санація (деепітелізація), висічення країв } \\
\text { оболонок, капітонаж із дренуванням }\end{array}$ & 105 & 40 & 145 \\
\hline Сегментарна резекція печінки & 10 & - & 10 \\
\hline $\begin{array}{l}\text { Транскутанна пункція, санація з дренуванням під ультрасоногра- } \\
\text { фічним і рентгенологічним контролем }\end{array}$ & 25 & 3 & 28 \\
\hline Лапароскопічно & 3 & 9 & 12 \\
\hline Всього & $212(73,87 \%)$ & $75(26,13 \%)$ & $287(100 \%)$ \\
\hline
\end{tabular}

органа). Показаннями для транскутанної пункції та дренування КП з ультрасонографічно-рентгенологічною асистенцією були глибоке інтрапаренхіматозне розташування кіст у складних анатомічних ділянках печінки, за умови, якщо можливо безпечно провести пункцію кісти таким способом. Якщо ж неможливо провести транскутанну пункцію глибоко розташованих кіст печінки, тоді використовували їх інтраабдомінальну пункцію та дренування. Інтраабдомінальну пункцію та дренування проводили або за допомогою ультрасонографії, або під дактилотактильним контролем.

Суть відкритого методу операції при кістах печінки полягала в лапаротомії, пункції, санації (чи деепітелізації), видаленні її вмісту, парціальному висіченні фіброзної капсули та зашиванні порожнини кісти 3 можливим дренуванням місця втручання. Під час операції необхідна ретельна ізоляція операційного поля для виключення потрапляння вмісту кісти на навколишні тканини (рис.). Після пункції та спорожнювання кісти в її просвіт вводили препарати, що дозволяють знешкодити збережені в ній сколекси (при ехінококо-
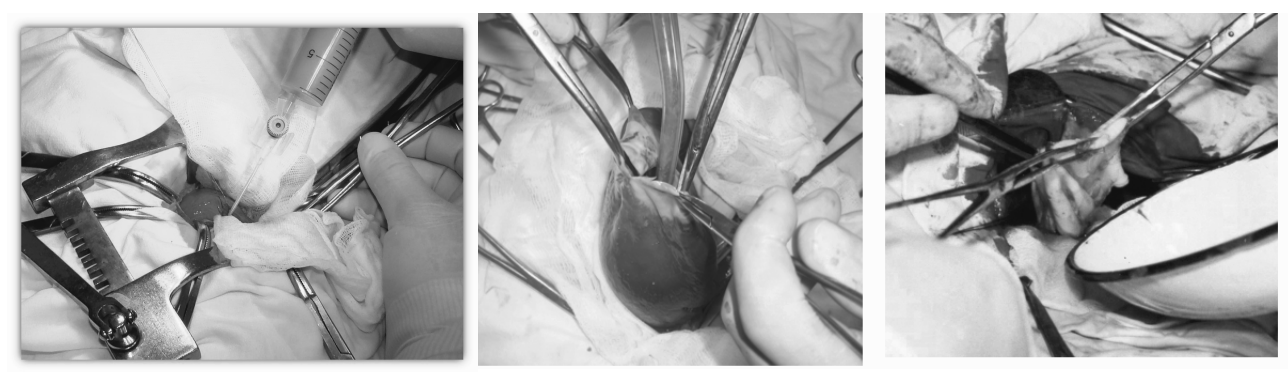

зі) або провести деепітелізацію (при непаразитарних кістах), і тільки після цього - розкривали фіброзну капсулу та евакуювали вміст з просвіту залишкової порожнини, яку повторно піддавали антипаразитарній обробці чи деепітелізації та висікали поверхневу частину фіброзної капсули.

Для ліквідації порожнини КП ми жодного разу не використовували оментопластику через те, що тампонований в кісті чепець $є$ додатковим джерелом кровопостачання в заздалегідь небезпечній ділянці, що є причиною рецидиву ехінококозу; оментопластика просвіту кісти призводить до формування фіброзу печінки в місці ураження та до виникнення злукового процесу черевної порожнини, що може стати причиною непрохідності кишок. Крім того, для ліквідації порожнини кісти ми не використовували відомі способи капітонажу за Дельбе або за Березкіним, тому що вони недостатньо ефективні.

При псевдопухлинному типі ЕКП виконували сегментарну резекцію печінки.

Хірургічний доступ при відкритому втручанні при КП залежав від посегментного розташування кіст і був

Рис. Етапи відкритої операції при кістах печінки.

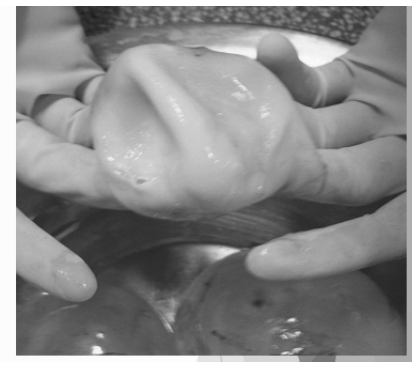


анатомічно локалізованим, мінімально травматичним і найраціональнішим при таких операціях - верхньосерединним, косо-поперечним у різних варіантах (за Кохером, за С. П. Федоровим, з переходом на X міжребер'я), трансторакальним із діафрагмотомією чи абдомінально-торакальним.

Для ліквідації порожнини КП запропоновано оригінальні способи капітонажу, які диференційовано використовували в кожному окремому випадку залежно від топографо-анатомічної локалізації.

З 2009 р. у клініці впроваджено лапароскопічні операції при кістозному ураженні печінки. Показаннями до лапароскопічної корекції КП були: кісти діаметром до 5 см, неускладнені ехінококові кісти без включень у вигляді дочірних міхурців і кісти правої або лівої трикутних зв'язок печінки.

Протипоказаннями вважали: перенесені операціїу верхній ділянці черевної порожнини, кісти діаметром більше 5 см, наявність дочірних міхурців всередині ехінококової кісти.

Антипаразитарний принцип проведення хірургічного втручання зводився до знезараження порожнини фіброзної капсули КП різними сколецидними середниками. Враховуючи дубильні властивості хімічних речовин або дубильний ефект фізичних методів впливу на внутрішню оболонку кісти, ці засоби також використовували для деепітелізації НКП. Основними позитивними характеристиками методів санації та деепітелізації КП вважали їх сколецидну ефективність, належні антисептичні властивості та мінімальний токсичний вплив на печінку та організм у цілому, що слугувало профілактикою рецидиву захворювання та запобігало появі ускладнень.

У НДСЛ «ОХМАТДИТ» запропонований ефективний метод антипаразитарної обробки ЕКП, що полягав у почерговому введенні 10 \% спиртового розчину йоду та 96 \% етилового спирту з експозицією по 7 хвилин кожен, з наступною повторною обробкою цими ж розчинами та 0,02 \% розчином хлоргексидину біглюконату, протягом 5 хвилин кожним, з подальшим розкриттям порожнини кісти та видаленням хітинової оболонки зі сколексами. Для деепітелізації НКП достатньо було почергової обробки ії розкритої порожнини тампонами з $10 \%$ спиртовим розчином йоду, $96 \%$ етиловим спиртом і 0,02 \% розчином хлоргексидину біглюконату, протягом 5 хвилин кожним.

Усі проліковані діти з КП перебували під динамічним спостереженням у ранній та віддалений (до 30 років після операції) період.
Після хірургічного лікування КП летальності не було. Ранні післяопераційні ускладнення виникли у $8(2,79 \%)$ із 287 дітей з КП.

Після відкритого хірургічного втручання у 2 пацієнтів з ЕКП у ранній післяопераційний період (на 7 та 11 добу) з'явились ознаки жовчної нориці. Причиною цього ускладнення було утворення пролежня жовчної протоки від близького контакту з дренажною трубкою. Цим дітям було видалено дренажні трубки, нориці самостійно закрились через 6 та 9 днів відповідно. У 4 пацієнтів з ЕКП після транскутанного пункційно-дренажного лікування в післяопераційний період протягом 4-10 діб зберігалася гіпертермія (до 38,0-40,0ㄷ) 3 ознобом. У 2 пацієнтів цієї групи було виявлено ознаки алергічно-токсичної нефропатії.

Інших післяопераційнихускладнень не відзначено.

Перебування в стаціонарі після відкритого хірургічного втручання становило $(15,32 \pm 1,02)$ дня $(p<0,05)$, після інтраабдомінальної пункції та дренування $(21,12 \pm 3,14)$ дня ( $>>0,05)$, після транскутанного пункційно-дренажного лікування - $(18,12 \pm 2,72)$ дня ( $>>0,05)$, а після лапароскопічного - $(8,24 \pm 2,36)$ дня $(p>0,05)$.

У віддалений період після хірургічної корекції КП як паразитарної, так і непаразитарної етіології типових ускладнень (нагноєння залишкової порожнини, жовчні нориці, рецидив) не виявлено.

Наші спостереження показали, що повна облітерація ліквідованої порожнини кісти любого генезу настає не в ранній період, а цей процес закінчується у віддалений післяопераційний період за умови раціонально виконаних технічних операційних прийомів, ефективної дії санаційних препаратів та регенеративних властивостей печінки. Всі прооперовані діти перебували під нашим динамічним спостереженням, під час якого за допомогою сучасних променевих методів дослідження (ультрасонографія, допплерографія, КТ) було констатовано та достовірно доведено відсутність рецидиву захворювання.

Отже, розроблені в НДСЛ «ОХМАТДИТ» методи хірургічного лікування пацієнтів із КП дозволили уникнути летальності та появи післяопераційних ускладнень з досягненням повної відсутності рецидивів цього захворювання.

Висновки. 1.У лікуванні кістозних уражень печінки у дітей доцільно застосовувати диференційний підхід із використанням відкритих та закритих методів хірургічних втручань, у тому числі й міні-інвазивних, залежно від розташування та розмірів кіст. Кісти печінки, діаметр яких менший 1 см, підлягають спо- 
стереженню в динаміці. Показанням для хірургічного лікування таких кіст є збільшення їх розмірів.

2. В обсязі відкритої операції з приводу кіст печінки потрібно виділяти такі етапи: пункційно-дренажна декомпресія та санація (чи деепітелізація) кісти (1 етап), розкриття з видаленням хітинової оболонки (при ехінококозі) з наступною повторною санацією (чи деепітелізацією) порожнини (2 етап), висічення фіброзної капсули з капітонажем і пролонгованим дренуванням залишкової порожнини (за показаннями) (3 етап). При псевдопухлинному типі ехінококових кіст печінки необхідно виконувати сегментарну резекцію печінки.

\section{СПИСОК ЛІТЕРАТУРИ}

1. Джабраилов Д. А. Эхинококкоз печени, осложнённый цистодилиарными свищами: диагностика и тактика лечения / Д. А. Джабраилов // Анналы хир. гепатол. - 2008. № 4. - С. 5-9.

2. Каримов Ш. И. Лапароскопические и видеоассистированные вмешательства в хирургии эхинококкоза печени / Ш. И. Каримов, Н. Ф. Кротов, С. Мамараджабов // Анналы хир. гепатол. - 2007. - № 4. - С. 91-96.

3. Хирургическое лечение абдоминального эхинококкоза / Р. Т. Меджидов, М. А. Алиев, Р. М. Гамзатов, Ш. Р. Меджидов // Анналы хир. гепатол. - 2007. №1. - C. 43-48.

4. Пулатов А. Т. Эхинококкоз в детском возрасте / А. Т. Пулатов. - М. : Медицина, 2004. - С. 148-157.

5. Салимов Ш. Т. Видеолапароскопия как выбор метода лечения при эхинококкозе печени у детей / Ш. Т. Салимов, Б. З. Абдусаматов, А. Ш. Вахидов // Актуальные вопросы детской хирургии : сб. научн. тр. 5-й Респ. научно-практической конф. по детской хирургии, посвященной 40-летию Детского хирургического центра и каф. детской хирургии БГМУ : в 2 ч. ; под общ. ред. В. И. Аверина. Минск : БГМУ, 2010. - С. 370-372.
3. Міні-інвазивний транскутанний пункційнодренажний метод лікування кіст печінки зультрасонографічно-рентгенологічною асистенцією варто застосовувати при інтрапаренхіматозно розташованих порожнинах діаметром не менше $3 \mathrm{~cm}$.

4. Лапароскопічні втручання доцільні при поверхнево розташованих кістах печінки на передньо-нижній поверхні цього органа.

5. Диференціація патогенетичних варіантів кіст печінки визначає вибір способів хірургічних доступів, методів корекції та післяопераційного ведення пацієнтів, що суттєво впливає на перебіг післяопераційного періоду та кінцевий прогноз хірургічного лікування.

6. Percutaneous imaging-guided treatment of hydatid liver cysts: Do long-term results make it a first choice? / A. Kabaalioglu, K. Ceken, E. Alimoglu, A. Apaydin // Eur. J. Radiol. - 2006. - Vol. 59. - P.65-73.

7. Moro P. Cystic echinococcosis in the Americas / P. Moro, P. M. Schantz // Parasitology International. - 2006. Vol. 55. - P. 181-186.

8. Smego Jr. R. A. Treatment options for hepatic cystic Echinococcosis / Jr. R. A. Smego, P. Sebanego // Intern. J. Infect. Dis. - 2005. - Vol. 9. - P. 69-76.

9. Somily A. Echinococcal disease in Alberta, Canada: more than a calcified opacity / A. Somily, J. L. Robinson, L. J. Miedzinski [et al.] // BMC Inf. Dis. - 2005. - Vol. 5. P. 34-43.

10. First report of a human case of polycystic echinococcosis due to Echinococcus vogeli from neotropical area of Peru, South America / J. R. Somocurcio, E. L. Sanchez, C. Naquira [et al.] // Rev. Inst Med. Trop. Sao. Paulo. - 2004. - Vol. 46. P. 41-42.

11. Hydatid disease involving some rare locations in the body: a pictorial essay / M. Yuksel, G. Demirpolat, Sever [et al.] // Korean J. Radiol. - 2007. - Vol. 8. - P. 531-540.

12. Дані первинної облікової документації (архівні) НДСЛ «Охматдит». - Форма 003/о. 